\title{
Ancestry informative markers and complete blood count parameters in Brazilian blood donors
}

\author{
Marcadores informativos de ancestralidade e parâmetros no hemograma de doadores de sangue \\ brasileiros
}

\author{
Gabriela E. S. Felix ${ }^{1}$ \\ Kiyoko Abe-Sandes ${ }^{2}$ \\ Taísa M. Bonfim ${ }^{3}$ \\ Maria T. Bendicho ${ }^{4}$ \\ Patrícia Cisneiros ${ }^{5}$ \\ Rosalina Guedes ${ }^{1}$ \\ Cláudio J. F. Brandão \\ Alex J. L. Torres ${ }^{7}$ \\ Carlos Brites ${ }^{8}$ \\ Eduardo M. Netto ${ }^{9}$ \\ Roberto Meyer ${ }^{10}$ \\ Songeli M. Freire ${ }^{I I}$
}

\begin{abstract}
A complete blood count is very useful in clinical diagnoses when reference ranges are well established for the population. Complete blood counts and allele frequencies of Ancestry Informative Markers (AIMs) were analyzed in Brazilians with the aim of characterizing the hematological values of an admixed population. Positive associations were observed between gender and neutrophils, monocytes, eosinophils, erythrocytes, hemoglobin, hematocrit, $M C V, M C H C$ and platelet counts. No significant differences were found for age, alcohol consumption, educational status, ethnicity, smoking in respect to the complete blood count values. In general, men had higher red blood cell values, while women had higher values for white blood cells and platelets. The study of the population was highly heterogeneous with mean proportions ( $\pm S E$ ) of African, European and Amerindian ancestry being $49.0 \pm 3.0 \%, 44.0 \pm 9.0 \%$ and $7.0 \pm 9.0 \%$, respectively. Amerindian ancestry showed limited contribution to the makeup of the population, but estimated ancestral proportions were statistically significant $(r=0.9838$; $P<0.001)$. These hematologic values are similar to Afro-Americans, another admixed population. Rev. Bras. Hematol. Hemoter. 2010;32(4):282-285.
\end{abstract}

Key words: Blood cell count; blood donors; genetic markers.

\footnotetext{
${ }^{1}$ Biomédica. Laboratório de Imunologia e Biologia Molecular, Instituto de Ciências da Saúde, Universidade Federal da Bahia. ${ }^{2}$ Bióloga. Professor pleno da Universidade do Estado da Bahia, pesquisador colaborador do Centro de Pesquisa Gonçalo Moniz-Fiocruz. ${ }^{3}$ Bióloga da Universidade Federal da Bahia - UFBA.

${ }^{4}$ Farmacêutica bioquimica da Universidade Federal da Bahia e Professor Assistente da Escola Bahiana de Medicina e Saúde Pública. ${ }^{5}$ Bióloga. Técnica de laboratório (superior), Laboratório de Imunologia e Biologia Molecular, Instituto de Ciências da Saúde, UFBA. ${ }^{6}$ Farmacêutico. Professor de Coagulação, Hemostasia e Hemoterapia no Curso de Especialização em Análises Clínicas da Faculdade de Farmácia da UFBA; Bioquímico e Supervisor Bioquímico do Hospital Aliança, Bahia; Bioquímico do Hospital Ana Neri, Bahia ${ }^{7}$ Biólogo. Responsável pela citometria de fluxo do Laboratório de Pesquisa em Infectologia do Complexo Hospitalar Universitário Professor Edgard Santos, Consultor e Membro do Grupo Técnico da rede de laboratórios do Programa Nacional DST e AIDS do Ministério da Saúde. ${ }^{8}$ Médico. Professor Adjunto de Infectologia da Faculdade de Medicina, da Universidade Federal da Bahia. Coordenador do Laboratório de Pesquisas em Virologia, do Hospital Professor Edgard Santos-UFBA.

${ }^{9}$ Médico epidemiologista da Universidade Federal da Bahia e professor de Bioestatística da CPgMS/UFBA (2006).

${ }^{10}$ Médico. Professor Associado da Universidade Federal da Bahia. Professor fundador do curso de Imunologia Básica e membro fundador do Programa de Pós-graduação em Imunologia da UFBA.

${ }^{11}$ Farmacêutica bioquímica. Professora do Programa de Pós-graduação em Imunologia da UFBA. Professora Adjunto de Imunologia Básica e Imunologia Clínica e colaboradora dos cursos de pós-graduação da Escola Bahiana de Medicina e Saúde Pública. Laboratório de Imunologia e Biologia Molecular, Instituto de Ciências.
}

Laboratório de Imunologia e Biologia Molecular, Instituto de Ciências da Saúde, Universidade Federal da Bahia - Salvador-BA.

Correspondência: Songeli M. Freire/Kiyoko Abe-Sandes

Laboratório de Imunologia e Biologia Molecular, Instituto de Ciências da Saúde, Universidade Federal da Bahia Av. Reitor Miguel Calmon $s / n$, Vale do Canela

40110-100 - Salvador-BA - Brazil

Tel.:/Fax.: (55 71) 3235-9682

E-mail:gesfelix@yahoo.com.br

Doi:10.1590/S1516-84842010005000074 
A complete blood count $(\mathrm{CBC})$ is one of the commonest tests used in clinical diagnosis. The result of a $\mathrm{CBC}$ vary depending on factors such as: age, gender, ethnicity and smoking. ${ }^{1-4}$ Benign neutropenia is a common condition associated to ethnicity as it is mostly described in African descendants. These individuals also present with low platelet and hemoglobin counts and high lymphocyte counts. ${ }^{2-4}$

Lugada et al. ${ }^{5}$ reported regional variations in some hematologic and immunologic indices between populations in African and the industrialized West. Studies using Ancestry Informative Markers (AIMs) showed that the Brazilian population is one of the most heterogeneous in the world resulting from an admixture process that began 500 years ago chiefly between Africans, Amerindians and Europeans ${ }^{6-7}$ AIMs are molecular markers of geographicaldependent distribution that have been used to estimate the degree of admixture of populations and individuals. ${ }^{8}$

Thus, due to variations in hematological reference values in Brazil, this study aims at evaluating the $\mathrm{CBC}$ and estimating ancestry using AIMs of unrelated healthy Brazilians.

\section{Material and method}

\section{Study population}

The study sample consisted of 289 (213 men and 76 women) subjects who donated blood at the Fundação de Hematologia e Hemoterapia da Bahia (Hemoba), Salvador, Bahia, Brazil, in 2006 and 2007. This research was approved by the Maternidade Climério de Oliveira Research Ethics Committee of the Universidade Federal da Bahia. All subjects signed informed consent forms and answered a socioeconomic questionnaire. These individuals were unrelated and seronegative for Chagas disease, HAV, HBV, HCV, HIV I and II, HTLV I and II and Syphilis (data provided by Hemoba). For DNA analysis, a random sample of 100 subjects (68 men and 32 women) was selected.

\section{Blood counts}

Venous blood samples were collected in a Greiner Vacuette ${ }^{\circledR}$ K3EDTA tube during the morning shift. The CBCs were performed in the Sysmex SF-3000 automated analyzer. This counter was calibrated every day as recommended by the manufacturer.

DNA Analysis

DNA samples were extracted using the Purigene ${ }^{\circledR}$ DNA Isolation Kit (D-500 Gentra Systems). The APO, AT3-I/D, PV92, GC-1F, GC-1S and Sb 19.3 loci were analyzed as described by Parra et al. ${ }^{9}$ and the LPL locus was analyzed as described by Machado. ${ }^{7}$

Statistical Analysis

The computer programs SPSS, ${ }^{10}$ EpiInfo 6.4d,
GENEPOP $^{11}$ and ADMIX $^{12}$ were used to select the 100 random samples, to analyze the population genetics and to estimate ancestry contribution. Independent variables considered were alcohol consumption, number of schooling years, self-defined ethnicity, gender, age and smoking. The parental population allele frequencies used were those described by Shriver et al. ${ }^{8}$

\section{Results}

\section{Sample characteristics}

Most participants were men (74\%). The mean age was 34 years old (range: 18 to 59 years - SD 9.5). The majority of the subjects interviewed identified themselves as black (49.5\%), and reported that they had never smoked (79.9\%) and occasionally consumed alcoholic beverages (47.4\%). Additionally most of the participants had completed high school (62.6\%).

\section{Blood counts}

The $\mathrm{CBC}$ values did not have normal distribution, although the median and mean values were very alike, which is a tendency to normal distribution (Table 1). There was no association between alcohol consumption, number of schooling years, age, ethnicity and smoking with blood parameters (95\% IC; $\mathrm{P}>0.05$; Wilcoxon test). However, positive correlations were found between gender and neutrophils, monocytes, eosinophils, erythrocytes, hemoglobin, hematocrit, $\mathrm{MCV}, \mathrm{MCHC}$ and platelet counts (95\% IC; $\mathrm{P}<0.05$; Wilcoxon test). Men presented with higher red blood cell (RBC) parameters except for MCV and RDW $\mathrm{SD}$. While women presented with higher values for white blood cell (WBC) parameters except for monocytes and eosinophils. Both genders had similar values for basophil counts. In addition, it was observed that women had higher values for platelet parameters, except for PDW, MPV and PLCR.

\section{Admixture estimates}

Analysis of all loci showed that the population was in Hardy-Weinberg equilibrium ( $\mathrm{P}=0.56)$. An analysis of the associations between loci gave a p-value $>0.05$, which was expected because the analyzed AIMs have different chromosome locations. These results suggest that no specific genetic structure is present in the population which is attributable to a high level of heterogeneity. The population admixture proportions were estimated based on a trihybrid model of ancestry contribution. The mean ancestry proportions ( $\pm \mathrm{SE}$ ) found were $49.0 \pm 3.0 \%$ African, $44.0 \pm$ $9.0 \%$ European, and $7.0 \pm 9.0 \%$ Amerindian. These results are highly significant $(\mathrm{r}=0.9838$; $\mathrm{p}$-value $<0.001)$. Table 2 shows the allele frequencies of the AIMs analyzed. The allele frequencies of the African, Amerindian and European populations were obtained from the study of Shriver et al. ${ }^{8}$ 
Table 1. Complete blood count by sex

\begin{tabular}{|c|c|c|c|c|c|c|}
\hline \multirow{3}{*}{ Parameter } & \multicolumn{6}{|c|}{ Sex } \\
\hline & \multicolumn{3}{|c|}{ Women $(n=76)$} & \multicolumn{3}{|c|}{$\operatorname{Men}(n=123)$} \\
\hline & Percentage & Mean & Median \pm SD & Percentage & Mean & Median \pm SD \\
\hline Erythrocyte, $\times 10^{6} / \mathrm{mL}^{*}$ & - & 4.56 & $4.54 \pm 0.33$ & - & 5.12 & $5.13 \pm 0.48$ \\
\hline Hemoglobin, g/dL* & - & 13.10 & $13.23 \pm 0.95$ & - & 14.80 & $14.83 \pm 1.22$ \\
\hline Hematocrit, \%* & - & 39.85 & $40.36 \pm 2.68$ & - & 44.70 & $44.72 \pm 3.81$ \\
\hline $\mathrm{MCV}, \mathrm{fL}^{*}$ & - & 89.40 & $88.28 \pm 7.41$ & - & 87.70 & $87.50 \pm 4.69$ \\
\hline $\mathrm{MCH}, \mathrm{pg}^{\star \star}$ & - & 29.20 & $29.16 \pm 1.62$ & - & 29.40 & $28.98 \pm 1.98$ \\
\hline $\mathrm{MCHC}, \mathrm{g} / \mathrm{dL}^{*}$ & - & 32.90 & $32.91 \pm 1.34$ & - & 33.20 & $33.10 \pm 1.15$ \\
\hline $\mathrm{RDW} S \mathrm{SD}, \mathrm{fL}^{* *}$ & - & 40.85 & $40.54 \pm 3.10$ & - & 39.30 & $39.54 \pm 3.35$ \\
\hline RDW CV, \%** & - & 13.30 & $13.39 \pm 0.62$ & - & 13.30 & $13.42 \pm 0.70$ \\
\hline Leukocytes, $\times 10^{3} / \mathrm{mL}^{* *}$ & - & 6.24 & $6.67 \pm 2,14$ & - & 5.90 & $6.17 \pm 1.77$ \\
\hline Neutrophils* & $56.32 \%$ & 3.58 & $3.86 \pm 1.68$ & $53.35 \%$ & 3.11 & $3.34 \pm 1.38$ \\
\hline Monocytes* & $5.82 \%$ & 0.33 & $0.37 \pm 0.14$ & $7.12 \%$ & 0.40 & $0.43 \pm 0.18$ \\
\hline Eosinophils* & $3.97 \%$ & 0.15 & $0.28 \pm 0.45$ & $5.26 \%$ & 0.20 & $0.36 \pm 0.46$ \\
\hline Lymphocytes ${ }^{\star *}$ & $33.35 \%$ & 1.97 & $2.12 \pm 0.63$ & $33.73 \%$ & 1.94 & $2.00 \pm 0.58$ \\
\hline Basophils** & $0.54 \%$ & 0.03 & $0.03 \pm 0.02$ & $0.53 \%$ & 0.03 & $0.03 \pm 0.02$ \\
\hline Platelet, $x 1000 / \mathrm{mL}^{*}$ & - & 271.50 & $280.54 \pm 57.96$ & - & 240.00 & $243.19 \pm 49.37$ \\
\hline$P D W, \mathrm{fL}^{* *}$ & - & 11.45 & $11.89 \pm 1.73$ & - & 12.10 & $12.27 \pm 1.67$ \\
\hline MPV, fL ${ }^{* *}$ & - & 10.35 & $10.23 \pm 1.30$ & - & 10.50 & $10.57 \pm 0.91$ \\
\hline PLCR, \%** & - & 28.30 & $27.95 \pm 6.93$ & - & 28.90 & $29.79 \pm 7.26$ \\
\hline
\end{tabular}

Note: Asterisks denote significant differences between sex and the hematologic parameter: $\mathrm{P}<0.05^{*}, \mathrm{P}>0.05^{* *}$

Table 2. Allele frequencies of the ancestry informative markers analyzed

\begin{tabular}{cccccccc}
\hline \multirow{2}{*}{ Population } & \multicolumn{6}{c}{ Ancestry Informative Markers - allele*1 } \\
\cline { 2 - 8 } & APO & AT3 & GC-1F & GC-1S & LPL & PV92 & Sb19.3 \\
\hline African & 0.420 & 0.858 & 0.853 & 0.069 & 0.971 & 0.225 & 0.415 \\
Amerindian & 0.977 & 0.061 & 0.339 & 0.542 & 0.442 & 0.792 & 0.645 \\
European & 0.925 & 0.282 & 0.156 & 0.607 & 0.492 & 0.152 & 0.903 \\
Brazilian & 0.770 & 0.560 & 0.570 & 0.245 & 0.723 & 0.310 & 0.710 \\
\hline
\end{tabular}

Note: The allele frequencies for parental groups were obtained from the literature (Shriver et al. 2003)

\section{Discussion}

A strong association between blood counts and gender was observed in this current study. In general, women had higher values for the WBC and platelet parameters, while men presented higher values for RBC parameters. These finding are in agreement with previous studies (Note: see ${ }^{1-4}$ ). It trihybrid model (African, Amerindian and European) of ancestral contribution was established based on DNA analysis. A small contribution was observed for Amerindians (7.0\%) possibly due to convenience sampling and/or the sample size. Even so, a study performed by Machado ${ }^{7}$ also found a small contribution by Amerindians (14.5\%) compared with African (49.2\%) and European (36.3\%) populations. The hematological values, in particular the WBC parameters, described here are more similar to those described by Beutler \& West $^{3}$ and Hsieh et $a l .{ }^{4}$ for Afro-Americans than those described for Africans by Lugada et al., ${ }^{5}$ who reported lower values. The possible explanation for this is the high level of admixture of the current population, which is probably similar to the history of Afro-Americans. We also compared our results with those described by Malvezzi \& Pasquini ${ }^{13}$ from the southern region of Brazil, and found that for the WBC parameters the current work reports slightly lower values, except for lymphocyte and basophil counts. All these findings suggest that the other intrinsic (e.g. gender, immunologic status, genetic) and extrinsic (e.g. environment, diet, lifestyle) factors may, potentially, interfere with hematological counts. Thus, in agreement with Beutler \& West, ${ }^{3}$ the establishment of different reference ranges for different ethnic groups does not solve the problem since all people represent a degree of admixture. Moreover, the clinical diagnosis of one individual should consider not only signs and symptoms but also the age, gender, ethnic background, diet, smoking and alcohol consumption, as these have been described in previous 
studies as factors that interfere in hematological parameters as was also observed in this study with gender. These factors should also be considered when establishing reference ranges.

Moreover, we did not observe differences considering age, educational status, alcohol consumption and smoking with the blood parameters although this might be due to convenience sampling. In this study, the main aims were achieved; we observed a strong and significant association between gender and blood parameters, and also demonstrated that the Brazilian population is highly admixed. Nevertheless, further research with a larger sample population might explore differences between some other extrinsic/intrinsic factors and blood counts in this admixed population.

\section{Resumo}

O hemograma é muito útil no diagnóstico quando o intervalo de referência é adequadamente estabelecido para população. Como objetivo de verificar os valores hematológicos em população heterogênea foi analisado o hemograma e frequências alélica de marcadores informativos de ancestralidade de brasileiros. Foi observada associação positiva entre sexo e os valores de neutrófilos, monócitos, eosinófilos, eritrócitos, hemoglobina, hematócrito, MCV, MCHC e plaquetas (IC 95\%; P<0,05). E não houve diferenças entre idade, consumo de álcool, nível educacional, etnia, tabagismo e os valores do hemograma (IC 95\%; P>0,05). Os homens apresentaram valores maiores no eritrograma, enquanto no leucograma e plaquetograma foram as mulheres. Foi observado também que a população é altamente heterogênea $e$ as médias proporcionais $( \pm D P)$ de ancestralidade Africana, Europeia e Ameríndia estimada foram: 49,0 $03,0 \%, 44,0 \pm 9,0 \%$ e 7,0土9,0\%, respectivamente. A contribuição ancestral ameríndia se demonstrou pequena, mas a estimativa de proporções ancestrais foi estatisticamente significante $(r=0,9838 ; P<0,001)$. Os valores hematológicos aqui descritos são parecidos com os descritos em negros americanos, outra população heterogênea. Rev. Bras. Hematol. Hemoter. 2010;32 (4): 282-285.

Palavras-chave: Contagem de células sanguíneas; doadores de sangue; marcadores genéticos.

\section{Acknowledgements}

The authors wish to thank the following institutions for financial and strategic support: Conselho Nacional de Desenvolvimento Científico e Tecnológico (CNPq); Fundação de Amparo a Pesquisa no Estado da Bahia (Fapesb); Laboratório de Imunologia e Biologia Molecular (Labimuno), Instituto de Ciências da Saúde (ICS), Universidade Federal da Bahia (UFBA) and Fundação de Hematologia e Hemoterapia da Bahia (Hemoba).

\section{References}

1. Bain BJ, Seed M, Godsland I. Normal values for peripheral blood white cell counts in women of four different ethnic origins. J Clin Pathol. 1984;37(2):188-93.

2. Bain BJ. Ethnic and sex differences in the total and differential white cell count and platelet count. J Clin Pathol. 1996;49(8): 664-6.

3. Beutler E, West C. Hematologic differences between AfricanAmericans and whites: roles of iron deficiency and alphathalassemia on hemoglobin levels and mean corpuscular volume. Blood. 2005;106(2):740-5

4. Hsieh MM, Everhart JE, Byrd-Holt DD, Tisdale JF, Rodgers GP. Prevalence of neutropenia in the U.S. population: age, sex, smoking status, and ethnic differences. Ann Intern Med. 2007; 146(7):486-92.

5. Lugada ES, Mermin J, Kaharuza F, Ulvestad E, Were W, Langeland $\mathrm{N}$, et al. Population-based hematologic and immunologic reference values for a healthy Ugandan population. Clin Diagn Lab Immunol. 2004;11(1):29-34.

6. Abe-Sandes K, Silva JR WA, Zago MA. Heterogeneity of the Y chromosome in Afro-Brazilian populations. Hum Biol. 2004;76 (1):77-86.

7. Machado TMB. Ancestralidade em Salvador-BA [dissertation]. Salvador, Bahia, Brazil: Centro de Pesquisas Gonçalo Moniz/ Fiocruz, 2008.

8. Shriver MD, Parra EJ, Dios S, Bonilla C, Norton H, Jovel C, et al. Skin pigmentation, biogeographical ancestry and admixture mapping. Hum Genet. 2003;112(4):387-99.

9. Parra EJ, Marcine A, Akey J, Martinson J, Batzer M, Cooper R, et al. Estimating African American admixture proportions by use of population-specific alleles. Am J Hum Genet. 1998;63 (6):1839-51.

10. SPSS 16.0 Evaluation Version for Windows, Rel. 16.0.1. 2007. Chicago: SPSS Inc.

11. Raymond M, Rousset F. Genepop (version 1.2). Population genetics software for exact tests and ecumenicism. J. Hered. $1995 ; 86: 248-9$

12. Chakraborty, R. Gene identity in racial hybrids and estimation of admixture rates. In: Ahuja, YR, Neel JV, editors. Genetic differentiation in human and other animal populations. Indian Anthropological Association. 1985:171-80.

13. Malvezzi M, Pasquini R. Valores normais de leucócitos em população adulta de Curitiba. Boletim da Sociedade Brasileira de Hematologia e Hemoterapia. 1987;144:83-9.

Suporte Financeiro: Conselho Nacional de Desenvolvimento Científico e Tecnológico (CNPq); Fundação de Amparo a Pesquisa no Estado da Bahia (Fapesb); Laboratório de Imunologia e Biologia Molecular (Labimuno).

Avaliação: Editor e dois revisores externos

Conflito de interesse: sem conflito de interesse

Recebido: 26/11/2009

Aceito após modificações: 13/04/2010 